\title{
Reduction and Degradation Behaviour of Sinter under Simulated Vertical Probe Trial Condition
}

\author{
Rahamatulla JAFFARULLAH, Angamuthu ARUMUGAM, Vijay Krishna JHA \\ and Vaidyanathan NARAYANAN
}

Iron \& Sinter Division, Research \& Development Centre for Iron \& Steel (RDCIS), SAIL, P.O. Doranda, Ranchi-834002, India. E-mail: jaffarullah@yahoo.com, htr@sail-rdcis.com

(Received on January 15, 2008; accepted on May 12, 2008)

\begin{abstract}
Ferrous burden encounters several low temperature isotherms during descent in the blast furnace. Low temperature degradation of ferrous burden becomes critical particularly in the temperature region of $450-650^{\circ} \mathrm{C}$. The low temperature degradation, mainly of sinter, results in generation of fines, which affect gas permeability in the stack region. A severe reduction degradation of sinter hampers permeability causing imbalance in reduction degree in the radial and circumferential direction and disturbs the furnace heat levelall detrimental to stability of furnace operation.

Experimental studies were carried out with the following conditions: Temperature: 550, 650, 900 and $1000^{\circ} \mathrm{C}$; soaking time: 30,60 and $90 \mathrm{~min}$, and Gas composition corresponding to Softening-melting test condition (CO-40\% and $\mathrm{N}_{2}-60 \%$ ) and Vertical Probe trial condition ( $\eta_{\mathrm{CO}}-40 \%$ and $\left.\eta_{\mathrm{CO}}-30 \%\right)$. Degradation takes place both at low temperature $\left(550\right.$ and $\left.650^{\circ} \mathrm{C}\right)$ and high temperature $\left(900\right.$ and $\left.1000^{\circ} \mathrm{C}\right)$ reduction of sinter simulated under Vertical Probe trial condition. Reducibility was appreciably lower for all tests carried out under simulated Vertical Probe trial condition compared with the results obtained using Softening-melting test condition.

Results clearly showed that for minimizing sinter degradation and improving reduction degree in the blast furnace, low temperature holding zone has to be avoided and high temperature holding zone has to be minimized. This can be achieved by increasing sinter reduction degree by adjusting sinter chemistry and burden distribution in blast furnace.
\end{abstract}

KEY WORDS: blast furnace; vertical probe; softening-melting; reduction degree; ferrous burden; degradation; holding zone; transition zone; cohesive zone; thermal reserve zone; mineralogical phases.

\section{Introduction}

Ferrous burden encounters several low temperature isotherms during it's descend in the blast furnace (BF). In the low temperature zone, the hematite present in burden reduces to a 'porous' magnetite, leading to the structural breakdown of ferrous material. The severity of material degradation or disintegration is denoted by the RDI value. Low temperature degradation of ferrous burden becomes critical particularly in the temperature region of 500$700^{\circ} \mathrm{C}$. ${ }^{1)} \mathrm{RDI}$ is considered to be an extremely important parameter for ferrous materials.

Several studies ${ }^{2-4)}$ have shown that low temperature reduction degradation has a very large impact on furnace performance. The low temperature degradation, mainly of sinters, result in generation of fines, which affect gas permeability in the stack region. For example, Thyssen Stahl ${ }^{2}$ found strong correlation between low temperature degradation and fuel rate, as fines cause peripheral gas flow leading to higher heat losses and fuel rate. It has also been considered that increase in reduction degradation resulted in reduced productivity and unstable furnace operation. A severe reduction degradation of sinter hampers permeability, causes imbalance in reduction degree in the radial and circumferential direction, and disturbs the furnace heat level, all detrimental to stability of furnace operation.

When large quantities of auxiliary fuel are injected, greater importance is attached to the properties of the burden and coke because of the increased residence time of charge materials in the furnace. Degradation of the ferrous burden and coke is increased considerably and also longer alkali attack. Vertical probe (VP) measurements and dissection studies of blast furnace showed that the cohesive zone begins at a temperature of above $1200^{\circ} \mathrm{C}$ corresponding to an $\eta_{\mathrm{CO}}$ of $5-7 \%$, depending on the tuyere gas temperature and composition and melts down at $1300-1400^{\circ} \mathrm{C}$, corresponding to an $\eta_{\mathrm{CO}}$ of $0 \%{ }^{4)}\left(\eta_{\mathrm{CO}}=\% \mathrm{CO}_{2} /\left[\% \mathrm{CO}+\% \mathrm{CO}_{2}\right]\right)$.

Figure 1 shows the formation of thermal and chemical reserve zone in the $\eta_{\mathrm{CO}}$ range of around $30 \%$ and of the holding zone at $\eta_{\mathrm{CO}}$ of around $40 / 45 \%$ has an adverse influence in blast furnace performance. This is reflected in an increase in direct reduction and a diminution of indirect reduction, accompanied by a higher top gas temperature. The holding zones at $\eta_{\mathrm{CO}}$ of around $40 / 45 \%$ are attributable to the degradation of the burden materials. VP measurements show that $\eta_{\mathrm{CO}}$ of $40 / 45 \%$ will be associated with a temper- 


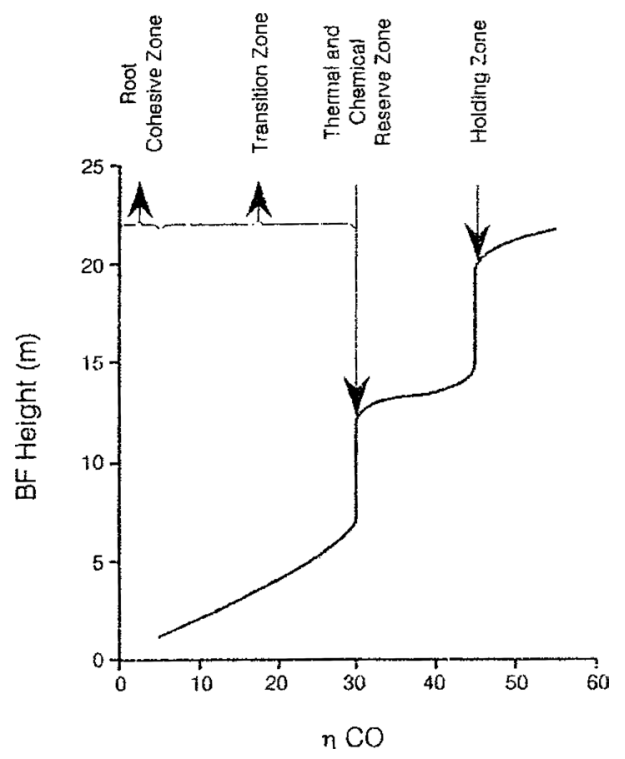

Fig. 1. Possible gas flow ranges along BF height at the periphery.

ature of $500-700^{\circ} \mathrm{C}$ at which the degradation of sinter and pellets readily occurs. ${ }^{4}$

High temperature sinter degradation was not known before the investigations of Peters et al. $^{4)}$ in the temperature range of around $900^{\circ} \mathrm{C}$ and at $\eta_{\mathrm{CO}}$ of about $30 \%$. Results of studies by Peters et al. showed that the degradation values at $900^{\circ} \mathrm{C}$ are about four times higher than at $550^{\circ} \mathrm{C}$ (i.e. sinter degradation is much more pronounced in the $900^{\circ} \mathrm{C}$ temperature range than at around $550^{\circ} \mathrm{C}$ ).

In a $\mathrm{BF}$, the gaseous or indirect reduction process occurring in the shaft is extremely important and occurs from the stockline to the lower region of the thermal reserve zone, where temperatures are around $950^{\circ} \mathrm{C}$. Reducibility is the ease with which the oxygen combines with iron can be removed indirectly. A higher reducibility means a greater extent of indirect reduction that may be obtained in the blast furnace resulting in a lowered coke rate and higher productivity.

Sinters are primarily made up of four main phases: Hematite, Magnetite, Silico-ferrite of calcium and aluminium (SFCA) and Silicates. ${ }^{5)}$ SFCA is considered to be the preferred tough bonding phase as it does not reduce at low temperature and quite resistant to crack propagation because of the presence of pores. When a crack runs into a non-angular pore, the stress intensity at the crack tip causing crack propagation is lowered. ${ }^{3)}$ It is well established that the inherent reducibility of phase in iron ore agglomerates decreases in the following order: Hematite, SFCA and Magnetite. But sinters have higher reducibility than lump ores, because SFCA plays an important role in maintaining intra particle porosity of sinter particles at high temperatures (upto $900^{\circ} \mathrm{C}$ ). ${ }^{6}$ )

Investigations by VP conducted in BF No. 5 of Bokaro Steel Plant (BSL) revealed, the formation of large holding zone corresponding to low temperature degradation isotherms of $450-650^{\circ} \mathrm{C}$, larger thermal reserve zone $\left(900-1000^{\circ} \mathrm{C}\right)$ and a delayed formation of cohesive zone at lower level with narrow transition zone nearer to tuyere region of blast furnace. This kind of temperature and gas profile will have a lower degree of indirect reduction leading to

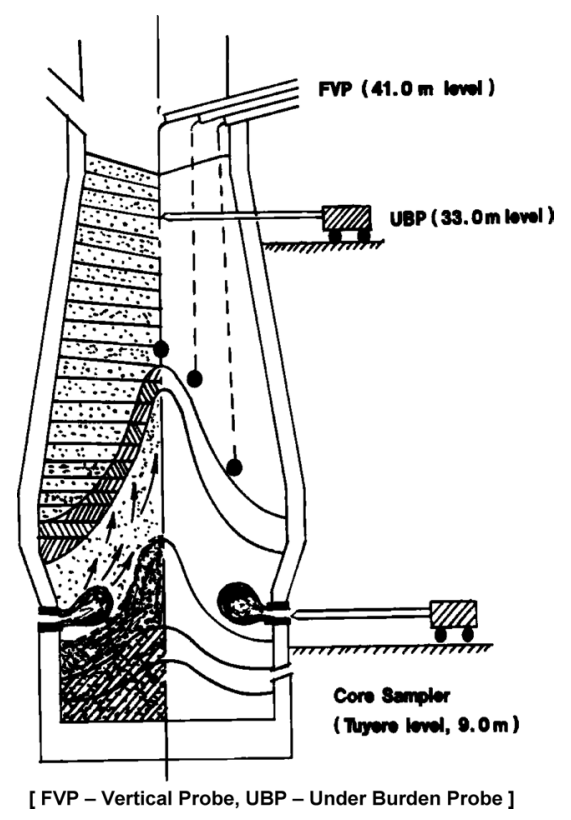

Fig. 2. Location of different probes at BF No. 5, BSL.

high coke rates and unstable operation of blast furnace.

In this context, experimental studies under simulated condition of VP trial data condition were carried out to study the effect of low and high temperature reduction and degradation characteristics and semi quantitative phase analysis of sinter using XRD. These studies will help in finding the ways to avoid holding zone formation and improving reduction degree of ferrous burden leading to coke economy, increased production and stable blast furnace operation.

\section{Experimental}

\subsection{Outline of Probes Installed in BF No. 5}

Figure 2 shows the location of Under Burden Probe (UBP), Vertical Probe (VP) and Core Sampler installed in BF No. 5, BSL. Both UBP and VP measure the temperature and pressure of the gas and collect the gas sample along the radius of the throat and along the height of the furnace. NKK designed VP was installed at $41.0 \mathrm{~m}$ level platform in BF No. 5 of BSL. The probe measures composition, temperature and pressure of the ascending gases along the height of the blast furnace from stock line to the cohesive zone at three radial points, i.e.; the periphery, intermediate and centre during its operation.

The Vertical Probe consists of a lance, guide pipes, probe cutting machines, feeding devices, probe supply drums and a control panel one each for the probes at periphery, intermediate and centre of BF. Fixed probe holder has been provided fixed at the shell of the furnace dome and directed towards the centre with built-in pipes to guide the probes into the blast furnace at the three locations mentioned above. Water-cooling system has been provided in the fixed probe holder to prevent its over-heating. The guide-pipes guide the probes from feeding device to the lance and prevent leakage of blast furnace gas from inside. When the probe reaches the cohesive zone $\left(1200^{\circ} \mathrm{C}\right)$, it is being cut automatically by a cutting machine installed near the feeding arrangement. The probe thereafter is pulled down by the 
movement of the burden material and is consumed inside the furnace.

\subsection{Vertical Probe Studies in BF No. 5}

More than 10 VP trials were conducted in BF No. 5 in wall, centre and intermediate position. Trials in intermediate region revealed the formation of large holding zone corresponding to low temperature degradation isotherms of $450-650^{\circ} \mathrm{C}$, larger thermal reserve zone $\left(900-1000^{\circ} \mathrm{C}\right)$ and a delayed formation of cohesive zone with narrow transition zone nearer to tuyere region of blast furnace (Fig. 3). This is because of heavy loading (high ore/coke ratio) of the intermediate zone, the equilibrium temperature between the descending burden material and ascending gases were delayed. The gas composition corresponding to low temperature holding zone of $450-650^{\circ} \mathrm{C}$ was having $\eta_{\mathrm{CO}}$ value of around $40-45 \%$. The thermal reserve zone $\left(850-950^{\circ} \mathrm{C}\right)$ was having $\eta_{\mathrm{CO}}$ value of around $30 \%$. Therefore, the VP simulation trial in laboratory set-up was done with the following gas composition:

$$
\begin{aligned}
& \eta_{\mathrm{CO}}-40 \% \text { gas composition }=\mathrm{CO}-25 \%, \\
& \mathrm{CO}_{2}-17 \%, \mathrm{H}_{2}-3 \% \text { and } \mathrm{N}_{2}-55 \% \\
& \eta_{\mathrm{CO}}-30 \% \text { gas composition }=\mathrm{CO}-29 \%, \\
& \mathrm{CO}_{2}-13 \%, \mathrm{H}_{2}-3 \% \text { and } \mathrm{N}_{2}-55 \%
\end{aligned}
$$

The initial UBP measurement has indicated a high peripheral working. The temperature at the peripheral region was high $\left(500-550^{\circ} \mathrm{C}\right)$ and $\eta_{\mathrm{CO}}$ values the lowest correspondingly indicating high gas flow in that region. The central region temperature was in the range of $300-400^{\circ} \mathrm{C}$. The temperature, in the intermediate region was the lowest and was in the range of $100-125^{\circ} \mathrm{C}$. Though $\eta_{\mathrm{CO}}$ value is the highest indicating highest gas utilization, the volume of gas passing through this region was the lowest due to less permeability. This kind of temperature and gas profile will have a lower degree of indirect reduction leading to high coke rates and unstable operation of blast furnace.

\subsection{Experimental Equipment Description}

The experiments were carried out in Softening-melting (SM) experimental set-up (Fig. 4). It consists of a Tammann furnace with graphite resistance heating element ca- pable of raising the temperature of the furnace to an operation level of $1600^{\circ} \mathrm{C}$, alumina reaction tube, graphite sample vessel, gas mass flow controllers, gas mixer, load applying device, melt-down product collecting chambers and a control board.

The sample vessel containing sinter is placed at the centre of the furnace with the help of supporting stand. The sample is heated through a programmed heating pattern in an attempt to simulate the blast furnace conditions existing between the stockline and the bosh. During heating, the sample is reduced by reducing gases supplied through a perforated bottom plate.

The bottom-perforated plate of the sample vessel has 5 holes of $8 \mathrm{~mm}$ dia. for passing gases $\left(\mathrm{CO}, \mathrm{CO}_{2}, \mathrm{~N}_{2}\right.$ and $\left.\mathrm{H}_{2}\right)$ and easy flow of molten products (metal and slag), which are then collected in a rotating chamber containing $10 \mathrm{com}-$ partments. The progress of reduction of the sample is monitored by analysis of the outlet gases using an online infrared gas analyzer for $\mathrm{CO}$ and $\mathrm{CO}_{2}$ and thermal conductivity analyzer for $\mathrm{H}_{2}$.

The apparatus is also provided with Supervisory Control and Data Acquisition (SCADA) system with application

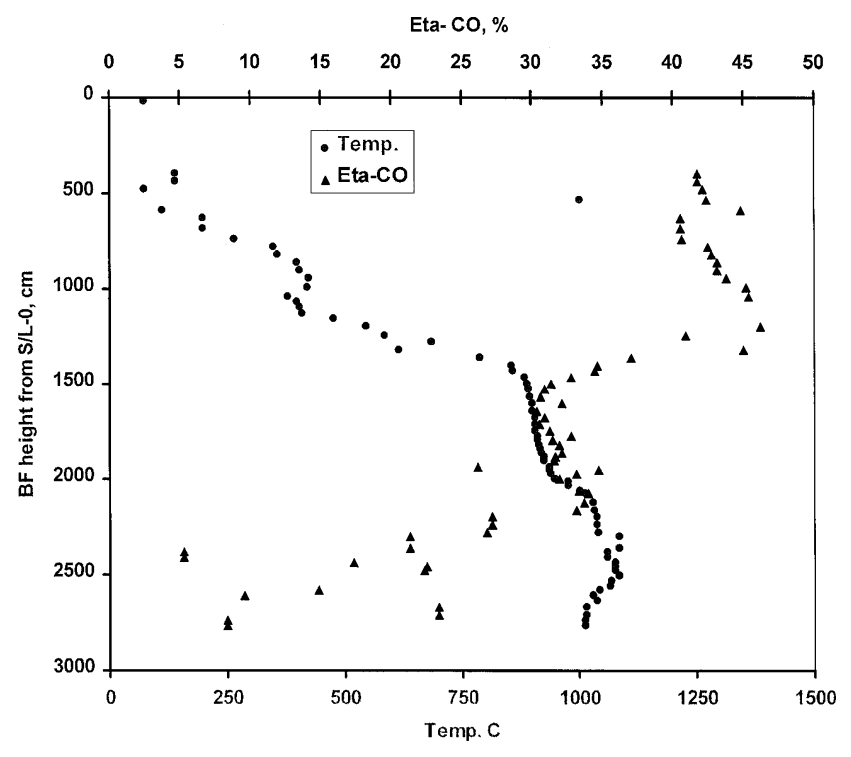

Fig. 3. VP measurement carried in BF No. 5 (intermediate region).

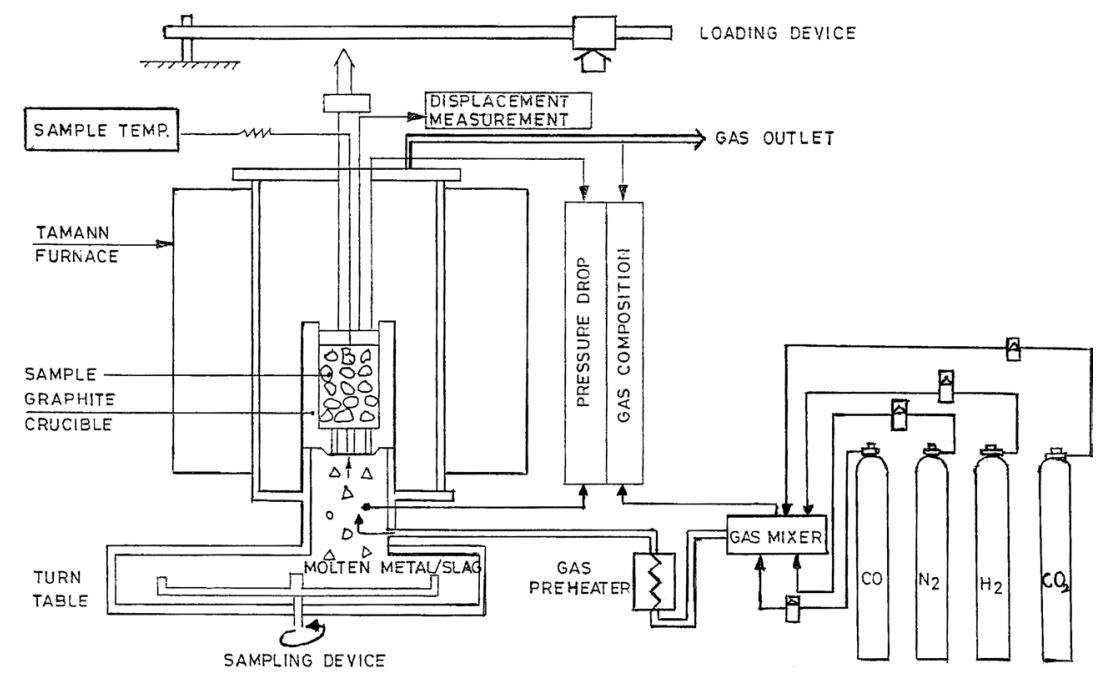

Fig. 4. Schematic diagram of softening-melting equipment. 
software for programming, control and monitoring of the complete experimental setup and for continuous logging of all the experimental data such as furnace and sample temperatures, degree of bed contraction, gas pressure drop across the bed and outlet gases composition.

Softening-melting test conditions are as follows:

Maximum temperature: $1600^{\circ} \mathrm{C}$

Sample bed diameter: $48 \mathrm{~mm}$

Sample bed height: $100 \mathrm{~mm}$

Particle size range: $\quad 8-10 \mathrm{~mm}$

Sample weight: $\quad$ Variable, constant bed height

Gas flow:

$7 \mathrm{~L} \mathrm{~min}^{-1}$ at NTP

Gas composition:

$0-200^{\circ} \mathrm{C}: \mathrm{N}_{2}$ only,

$200-1600^{\circ} \mathrm{C}: 40 \% \mathrm{CO}$ and

$60 \%\left(\mathrm{~N}_{2}+\mathrm{H}_{2}\right)$

(For all coke operation $60 \% \mathrm{~N}_{2}$ only, no $\mathrm{H}_{2}$ )

Heating rate:

0-200 ${ }^{\circ} \mathrm{C}$ : manual

200-900 ${ }^{\circ} \mathrm{C}: 10^{\circ} \mathrm{C} \mathrm{min}^{-1}$

$900-1200^{\circ} \mathrm{C}: 3^{\circ} \mathrm{C} \mathrm{min}^{-1}$

$1200-1600^{\circ} \mathrm{C}: 5^{\circ} \mathrm{C} \mathrm{min}^{-1}$

Applied load:

$98.1 \mathrm{kPa}$ at $900^{\circ} \mathrm{C}$ up to end of the test

\subsection{Experimental Condition}

Sinter samples having size range of $16-19 \mathrm{~mm}$ were tested in SM equipment for reduction and degradation studies with the following test condition.

- Temperatures: 550, 650, 900 and $1000^{\circ} \mathrm{C}$

- Soaking time: 30, 60 and $90 \mathrm{~min}$, and

- Gas composition corresponding to SM test condition (CO $-40 \%$ and $\mathrm{N}_{2}-60 \%$ ), VP trial condition $\left(\eta_{\mathrm{CO}}-40 \%\right.$ and $\left.\eta_{\mathrm{CO}}-30 \%\right)$ and standard RDI test condition (CO $20 \%, \mathrm{CO}_{2}-20 \%$ and $\mathrm{N}_{2}-60 \%$ )

Where,

$$
\begin{aligned}
\eta_{\mathrm{CO}}-40 \% \text { gas composition }= & \mathrm{CO}-25 \%, \mathrm{CO}_{2}-17 \%, \\
& \mathrm{H}_{2}-3 \% \text { and } \mathrm{N}_{2}-55 \% \\
\eta_{\mathrm{CO}}-30 \% \text { gas composition }= & \mathrm{CO}-29 \%, \mathrm{CO}_{2}-13 \%, \\
& \mathrm{H}_{2}-3 \% \text { and } \mathrm{N}_{2}-55 \%
\end{aligned}
$$

Table 1 shows the results of experiments carried with the above test condition for a sinter sample having composition: Total $\mathrm{Fe}-54.15 \%, \mathrm{FeO}-8.77 \%, \mathrm{SiO}_{2}-6.21 \%$, $\mathrm{CaO}-10.68 \%, \mathrm{Al}_{2} \mathrm{O}_{3}-2.56 \%, \mathrm{MgO}-3.42 \%$.

Reduction degree/Reducibility is the percent weight loss of oxygen with respect to total oxygen combined with $\mathrm{Fe}$ of original sample. Reduction degradation is weight percent of $-2.8 \mathrm{~mm}$ sinter after tumbling the reduced sampled for 900 revolutions@30rpm. The semi quantitative phase analysis was done for a selected experimental samples using XRD equipment.

\section{Results and Discussion}

\subsection{Effect of Temperature on Reduction and Degrada- tion}

Figures 5 and $\mathbf{6}$ shows the effect of temperature on reduction degree and degradation for sinter samples tested under simulated SM test gas composition and VP trial condition respectively. All the samples were subjected to soak-
Table 1. Reduction degree and degradation trials of a sinter sample.

\begin{tabular}{|c|c|c|c|c|c|}
\hline S. No & $\begin{array}{c}\text { Temperature, } \\
{ }^{\circ} \mathbf{C}\end{array}$ & $\begin{array}{c}\text { Time, } \\
\text { Min. }\end{array}$ & Gas Composition & $\begin{array}{c}\text { Reduction } \\
\text { degree, \% }\end{array}$ & $\begin{array}{c}\text { Reduction } \\
\text { degradation, \% }\end{array}$ \\
\hline 1 & 550 & 30 & $\mathrm{CO}-40 \%$ \& $\mathrm{N}_{2}-60 \%$ & 31.2 & 13.0 \\
\hline 2 & 650 & 30 & $\mathrm{CO}-40 \%$ \& $\mathrm{N}_{2}-60 \%$ & 46.0 & 16.1 \\
\hline 3 & 900 & 30 & $\mathrm{CO}-40 \%$ \& $\mathrm{N}_{2}-60 \%$ & 64.9 & 14.5 \\
\hline 4 & 1000 & 30 & $\mathrm{CO}-40 \%$ \& $\mathrm{N}_{2}-60 \%$ & 72.0 & 11.4 \\
\hline 5 & 550 & 30 & Simulated to VP data* & 11.9 & 13.2 \\
\hline 6 & 550 & 60 & Simulated to VP data* & 13.7 & 13.2 \\
\hline 7 & 550 & 90 & Simulated to VP data* & 14.2 & 16.2 \\
\hline 8 & 900 & 30 & Simulated to VP data** & 35.2 & 11.8 \\
\hline 9 & 900 & 60 & Simulated to VP data** & 27.9 & 14.6 \\
\hline 10 & 900 & 90 & Simulated to VP data** & 31.6 & 10.4 \\
\hline 11 & 650 & 30 & Simulated to VP data* & 12.7 & 11.3 \\
\hline 12 & 1000 & 30 & Simulated to VP data** & 41.1 & 10.3 \\
\hline 13 & 550 & 30 & $\begin{array}{c}\text { CO-20\%, } \text { CO }_{2}-20 \% \text { \& } \\
\mathrm{N}_{2}-60 \%\end{array}$ & 6.0 & 11.2 \\
\hline
\end{tabular}

Note: * - $\mathrm{CO}-25 \%, \mathrm{CO}_{2}-17 \%, \mathrm{H}_{2}-3 \% \& \mathrm{~N}_{2}-55 \%\left[400-550 / 650^{\circ} \mathrm{C}\right]$ ** $-\mathrm{CO}-25 \%, \mathrm{CO}_{2}-17 \%, \mathrm{H}_{2}-3 \% \& \mathrm{~N}_{2}-55 \%\left[400-900 / 1000^{\circ} \mathrm{C}\right]$ - $\mathrm{CO}-29 \%, \mathrm{CO}_{2}-13 \%, \mathrm{H}_{2}-3 \%$ \& $\mathrm{N}_{2}-55 \%\left[900 / 1000^{\circ} \mathrm{C}\right]$

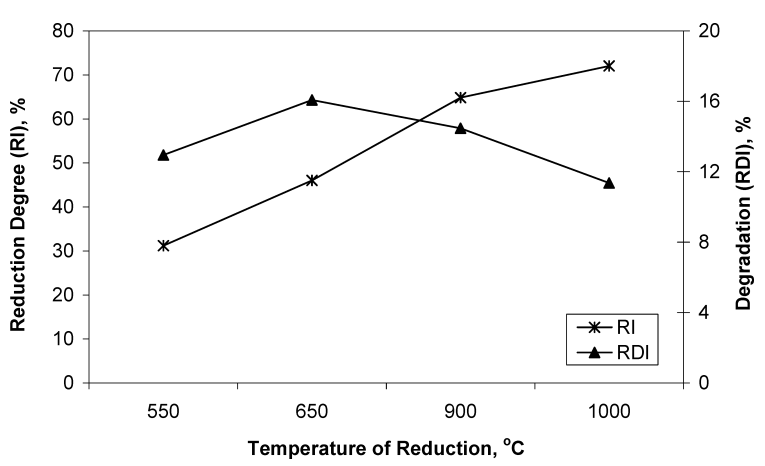

Fig. 5. Effect of temperature on reduction degree and degradation under SM test condition.

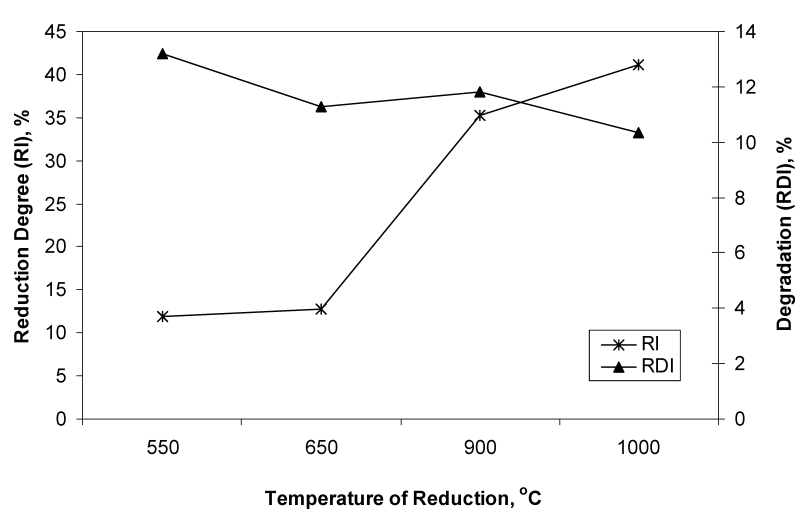

Fig. 6. Effect of temperature on reduction degree and degradation under simulated VP trial condition.

ing time of $30 \mathrm{~min}$ at different reaction temperatures (550, 650,900 and $1000^{\circ} \mathrm{C}$ ). Reduction degree increases with temperature from $31.2 \%\left(550^{\circ} \mathrm{C}\right)$ to $72.0 \%\left(1000^{\circ} \mathrm{C}\right)$ for SM test condition (Fig. 5). For VP trial condition (Fig. 6), reduction degree increases slightly from $11.9 \%\left(550^{\circ} \mathrm{C}\right)$ to $12.7 \%\left(650^{\circ} \mathrm{C}\right)$, but increases sharply to $35.2 \%\left(900^{\circ} \mathrm{C}\right)$ and $41.1 \%\left(1000^{\circ} \mathrm{C}\right)$.

The reduction degree results under simulated VP trial condition were lower than those obtained under SM test condition for all treatment temperature. The two main causes were low $\mathrm{CO}$ content in the gas and presence of $\mathrm{CO}_{2}$ in the gas mix for sinter samples treated under simulated 
VP trial condition. ${ }^{6)}$ Reduction degree is higher at high temperature treatment for both cases because of favourable reaction kinetics at higher temperature.

Degradation takes place both at low temperature (550 and $\left.650^{\circ} \mathrm{C}\right)$ and high temperature $\left(900\right.$ and $\left.1000^{\circ} \mathrm{C}\right)$ reduction for sinter samples tested under SM test condition and simulated VP trial condition. Degradation increases from $13.0 \%\left(550^{\circ} \mathrm{C}\right)$ to $16.1 \%\left(650^{\circ} \mathrm{C}\right)$. But, it decreases for high temperature: 900 and $1000^{\circ} \mathrm{C}$ tests with degradation of 14.5 and $11.4 \%$ respectively (Fig. 5). Lower degradation at higher temperature is due to the formation of metallic iron (softening of sinter) after wustite reduction. Similarly, low temperature degradation at $550^{\circ} \mathrm{C}$ is higher $(13.2 \%)$ compared to high temperature degradation at $900^{\circ} \mathrm{C}$ $(11.8 \%)$ for sinter samples treated under simulated VP trial condition (Fig. 6). Degradation at $650^{\circ} \mathrm{C}(11.3 \%)$ under simulated VP trial condition is showing a reverse trend compared to SM test condition.

\subsection{Effect of Soaking Time on Reduction and Degra- dation}

Figure 7 shows the effect of soaking time on reduction degree and degradation for sinter samples heated to low temperature $\left(550^{\circ} \mathrm{C}\right)$ under simulated VP trial condition. An increased gas-solid contact time would increase gaseous reduction. Thus, reduction degree increases with time from $11.9 \%$ (30 min soaking time) to $13.7 \%$ (60 min soaking time) and $14.2 \%$ (90 min soaking time). Degradation is similar with $13.2 \%$ for both cases of sinter samples treated with 30 min soaking time and 60 min soaking time, but increases to $16.2 \%$ ( $90 \mathrm{~min}$ soaking time). The fundamental cause of low temperature degradation is hematite reducing to magnetite, resulting in a volume expansion and relieving of stresses through the formation of cracks, which then become passages for the reducing gases to penetrate easily into the inner regions of sinter particles. ${ }^{3)}$ Hematite present along the walls of the cracks is then reduced, inducing new stresses and leading to the propagation of the formed crack or the formation of new cracks. ${ }^{3)}$ Thus, with increasing soaking time, more reduction of hematite takes place inducing more stresses continuously and hence higher degradation.

Figure 8 shows the effect of time on reduction degree and degradation for sinter samples heated to high temperature $\left(900^{\circ} \mathrm{C}\right)$ under simulated VP trial condition. Reduction degree decreases sharply with time from 35.2\% (30 min soaking time) to $27.9 \%$ (60 min soaking time) and then increases to $31.6 \%$ (90 min soaking time). Degradation increases with time from $11.8 \%$ (30 min soaking time) to $14.6 \%$ (60 min soaking time) and then decreases to $10.4 \%$ ( 90 min soaking time). There is a clear mirror image trend in both reduction and degradation effect. Reduction decreases in general at higher soaking time (60 and $90 \mathrm{~min}$ ) compared to lower soaking time $(30 \mathrm{~min})$, which may be due to the formation of metallic iron (softening of sinter) leading to closure of pores and re-oxidation by $\mathrm{CO}_{2}$ gas. However, this requires further investigation.

\subsection{XRD Analysis on Experimental Sinter Samples}

The semi quantitative phase analysis has been done for a selected experimental samples using XRD equipment

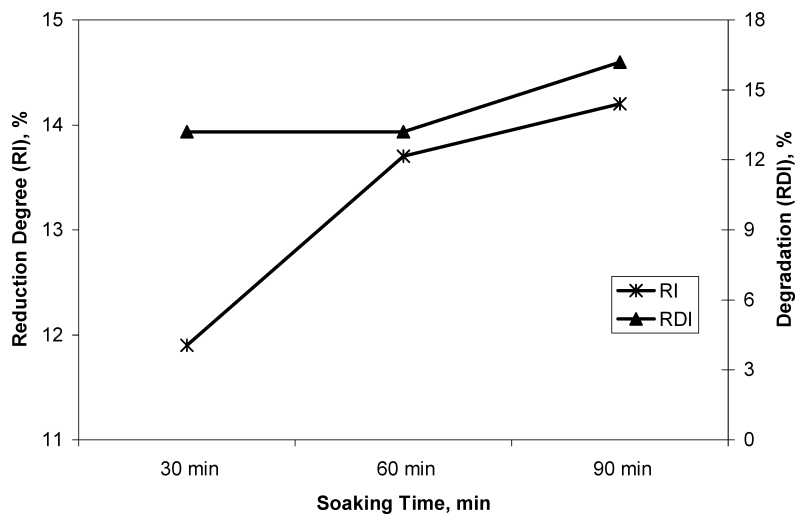

Fig. 7. Effect of time on reduction degree and degradation under simulated VP trial condition (temperature $-550^{\circ} \mathrm{C}$ ).

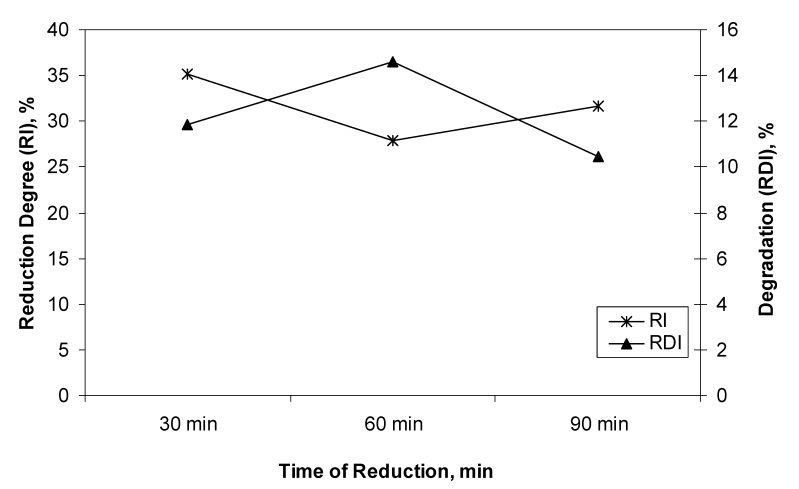

Fig. 8. Effect of time on reduction degree and degradation under simulated VP trial condition (temperature $-900^{\circ} \mathrm{C}$ ).

(Table 2). Figure 9 shows a typical XRD graph of a sinter sample with semi quantitative phase analysis. Figure 10 shows the quantity of major compound (phases) present/ transformed during reduction of the sinter samples compared to untreated sinter sample. The major phases present in the untreated sinter sample are magnetite $(45.3 \%)$, SFCA (17.5\%), magnesioferrite $(9.5 \%)$, hematite $(9 \%)$, dicalcium ferrite [non-stoichiometric] $(7.5 \%)$ and wustite $(6.4 \%)$.

Figure 10 shows that with reduction of sinter samples at low temperature $\left(550^{\circ} \mathrm{C}\right)$ magnetite and hematite phase reduces and transforms to wustite and metallic iron. SFCA reduced from $17.5 \%$ (untreated) to $7.7 \%\left(550^{\circ} \mathrm{C}-30 \mathrm{~min}\right.$ soaking time) and $5.1 \%\left(550^{\circ} \mathrm{C}-90 \mathrm{~min}\right.$ soaking time $)$ for sinter samples treated under simulated VP trial condition.

Figure 10 shows that with reduction of sinter samples at high temperature $\left(900^{\circ} \mathrm{C}\right)$ magnetite and hematite phases are transformed to wustite and metallic iron as a result of reduction. Iron formation is $58.6 \%$ for sinter sample treated with $900^{\circ} \mathrm{C}-30$ min soaking time under SM test gas composition compared to $23.6 \%$ for sinter sample treated with $900^{\circ} \mathrm{C}-30$ min soaking time under simulated VP trial condition. SFCA reduced from $17.5 \%$ (untreated) to $2.9 \%$ $\left(900^{\circ} \mathrm{C}-30 \mathrm{~min}\right.$ soaking time under SM test gas composition) and $4.0 \%\left(900^{\circ} \mathrm{C}-30 \mathrm{~min}\right.$ soaking time under simulated VP trial condition). It is clear that there is very little reduction of SFCA at low temperatures. 
ISIJ International, Vol. 48 (2008), No. 7

Table 2. Semi-quantitative phase analysis of sinter using XRD.

\begin{tabular}{|c|c|c|c|c|c|c|c|}
\hline \multirow{2}{*}{$\begin{array}{c}\text { Test Condition I } \\
\text { Compound }\end{array}$} & \multirow[t]{2}{*}{ Formula } & \multicolumn{6}{|c|}{ Sample Code } \\
\hline & & s1 & S2 & S3 & 54 & S5 & S6 \\
\hline Temperature, ${ }^{\circ} \mathrm{C}$ & & Untreated & 550 & 550 & 550 & 900 & 900 \\
\hline Gas composition, \% & & - & $\begin{array}{c}\mathrm{CO}-20 \% \\
\mathrm{CO}_{2}-20 \% \\
\mathrm{~N}_{2}-60 \%\end{array}$ & $\begin{array}{c}\mathrm{CO}-25 \% \\
\mathrm{CO}_{2}-17 \% \\
\mathrm{H}_{2}-3 \% \\
\mathrm{~N}_{2}-55 \%\end{array}$ & $\begin{array}{c}\mathrm{CO}-25 \% \\
\mathrm{CO}_{2}-17 \% \\
\mathrm{H}_{2}-3 \% \\
\mathrm{~N}_{2}-55 \%\end{array}$ & $\begin{array}{l}\mathrm{CO}-40 \% \\
\mathrm{~N}_{2}-60 \%\end{array}$ & $\begin{array}{c}\mathrm{CO}-29 \% \\
\mathrm{CO}_{2}-13 \% \\
\mathrm{H}_{2}-3 \% \\
\mathrm{~N}_{2}-55 \%\end{array}$ \\
\hline Soaking time, $\min$ & & - & 30 & 30 & 90 & 30 & 30 \\
\hline Hematite, $\%$ & $\mathrm{Fe}_{2} \mathrm{O}_{3}$ & 9.0 & 5.3 & 2.5 & 2.1 & 1.7 & 2.1 \\
\hline Magnetite, \% & $\mathrm{Fe}_{3} \mathrm{O}_{4}$ & 45.2 & 36.0 & 24.0 & 17.7 & 3.3 & 6.0 \\
\hline Wustite, \% & $\mathrm{FeO}$ & 6.4 & 12.0 & 12.3 & 9.5 & 11.6 & 22.8 \\
\hline Iron, \% & $\mathrm{Fe}$ & - & - & 0.8 & 8.1 & 58.6 & 23.6 \\
\hline SFCA, $\%$ & $\mathrm{Ca}_{5} \mathrm{Si}_{2}(\mathrm{FeAl})_{18} \mathrm{O}_{36}$ & 17.5 & 17.6 & 7.7 & 5.1 & 2.9 & 4.0 \\
\hline Calcium iron oxide, $\%$ & $\mathrm{CaFe}_{5} \mathrm{O}_{7}$ & - & - & - & - & - & 3.0 \\
\hline Dicalcium ferrite, $\%$ & $\mathrm{Ca}_{2} \mathrm{Fe}_{2} \mathrm{O}_{5}$ & 2.4 & 3.7 & 2.5 & 3.1 & 1.0 & 1.9 \\
\hline $\begin{array}{l}\text { Dicalcium iron oxide (non- } \\
\text { stoichiometric), } \%\end{array}$ & $\mathrm{Ca}_{2} \mathrm{Fe}_{15.6} \mathrm{O}_{25.6}$ & 7.5 & 5.9 & 2.8 & 2.5 & 1.6 & 2.1 \\
\hline Iron silicate, $\%$ & $\mathrm{FeSiO}_{3}$ & - & - & 16.2 & 17.4 & 7.1 & 9.8 \\
\hline Magnesio ferrite, $\%$ & $\mathrm{MgFe}_{2} \mathrm{O}_{4}$ & 9.5 & 14.8 & 11.3 & 15.5 & 3.4 & 9.4 \\
\hline Magnesium iron oxide, \% & $(\mathrm{MgO})_{0.24}(\mathrm{FeO})_{0.76}$ & 2.5 & 4.6 & 3.8 & 3.5 & 4.5 & 7.0 \\
\hline Wollastonite, $\%$ & $\mathrm{Ca}_{2.87} \mathrm{Fe}_{0.13}\left(\mathrm{SiO}_{3}\right)_{3}$ & - & - & 16.1 & 15.5 & 4.4 & 8.3 \\
\hline
\end{tabular}

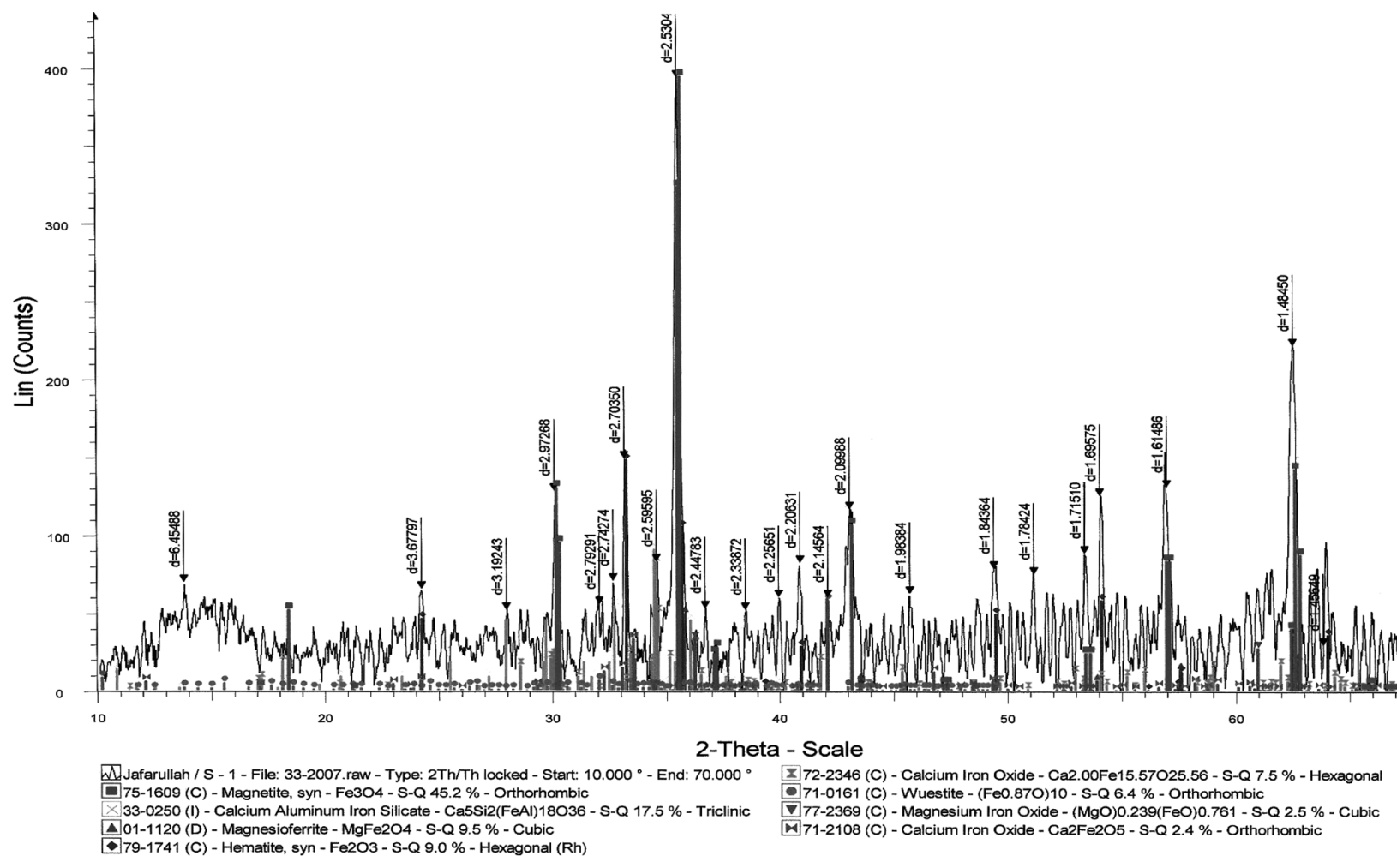

Fig. 9. XRD graph of untreated sinter sample.

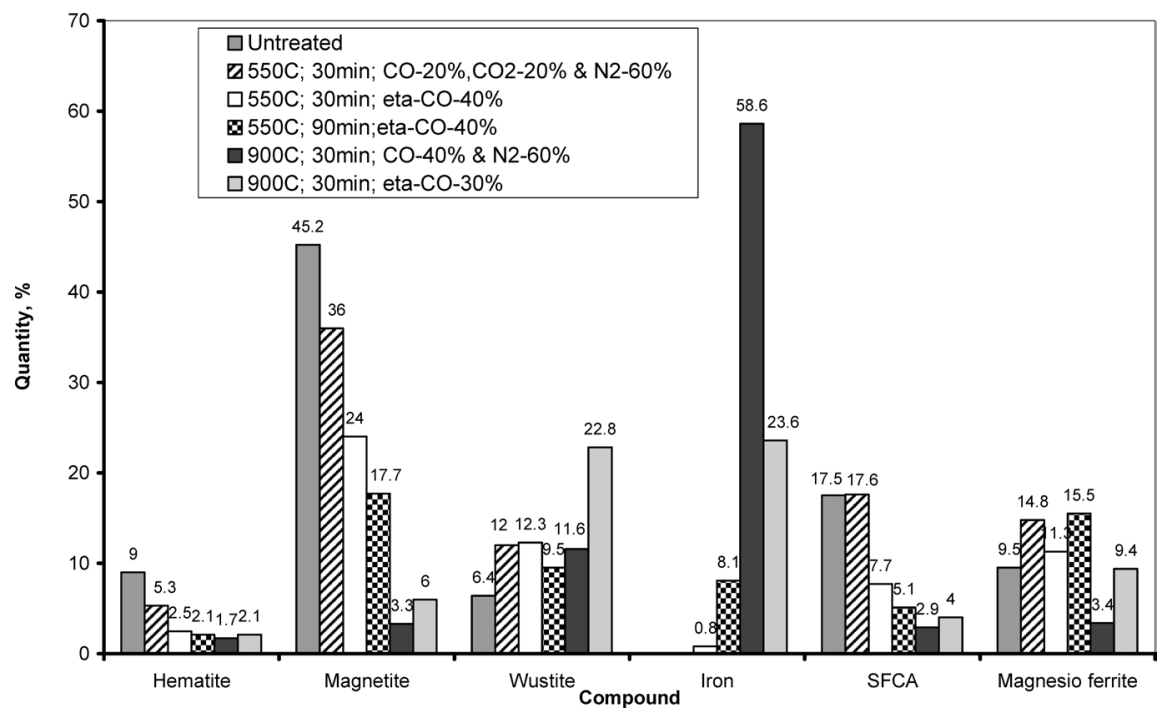

Fig. 10. Semi quantitative analysis of major phases in sinter samples by XRD. 


\subsection{Effect of Mineralogical Phases on Reduction and Degradation}

Malysheva et $a .^{7}{ }^{7}$ studied the influence of $\mathrm{MgO}$ on the phase transformations of sinter. In high-basicity magnesia sinter, where the basic ore phase is magnesium magnetite rather than magnetite, there is little ferrite formation, since the magnesium magnetite ceases to be a source of the iron required for SFCA. With increase in magnesium and decrease in the magnesium magnetite crystals, ferrite formation at the ore-melt contact is slower and the basicity of the residual silicate melt is higher as the slag components are not consumed in the formation of SFCA. Therefore, SFCA content in highly fluxed sinter gradually declines and the dicalcium silicate content increases. ${ }^{7)}$ This may be one of the reasons for low SFCA content of $17.5 \%$ in the untreated sinter sample. SFCA is highly porous phase and provides channels for reducing gases to flow into sinter particles, thus improving the reducibility of sinter. Low SFCA content will lead to lower reduction degree and more degradation.

Matsumura et al. ${ }^{8)}$ found that high $\mathrm{MgO}$ and high $\mathrm{FeO}$ sinter had low reduction degree at $900^{\circ} \mathrm{C}$. XRD pattern for the sinter indicated that it contained higher magnetite structure (magnetite and magnesioferrite) instead of hematite. ${ }^{8)}$ The untreated sinter sample is having high $\mathrm{MgO}(3.42 \%)$, high $\mathrm{FeO}(8.77 \%)$ and high $\mathrm{SiO}_{2}$ content $(6.21 \%)$ and therefore more magnetite $(45.3 \%)$ and magnesioferrite phases $(9.5 \%)$. This results in poor reduction degree of ferrous burden and formation of large holding zones in BF. Similarly, the reduction degree of sinter samples at high temperature $\left(900\right.$ and $\left.1000^{\circ} \mathrm{C}\right)$ under simulated VP trial condition is also low confirming the blast furnace VP investigations.

Yang and $\mathrm{Loo}^{9)}$ studied the properties and mineralogy of sinters produced from magnetite concentrates. The strength of the different mineral phases in the sinters was characterized using indentation techniques. Good correlations were obtained between tumble indices of the sinters and a composite fracture toughness of the major phases. Sinter displayed two typical bonding phase microstructures: SFCA/ magnetite associations and silicate glass. Sinter dominated by SFCA/magnetite structure is very strong. $\mathrm{MgO}$ in sinter influences the stabilization of magnetite formation, which then inhibits the formation of hematite and retards SFCA formation. Due to high $\mathrm{MgO}$, sinter phase of untreated sample is having higher magnetite $(45.3 \%)$, lower SFCA $(17.5 \%)$ and hematite content $(9.0 \%)$.

\section{Conclusions}

Reduction degree and degradation characteristics of a sinter sample with low temperature $\left(550\right.$ and $\left.650^{\circ} \mathrm{C}\right)$ and high temperature $\left(900\right.$ and $\left.1000^{\circ} \mathrm{C}\right)$ were investigated under simulated SM test condition and VP trial condition with varying soaking time. XRD semi quantitative analysis of selected experimental sample was done. The following results and conclusions were derived from the above studies:

(1) Reduction degree results under simulated VP trial condition were lower than those obtained under SM test condition for all treatment temperature. The two main causes were low $\mathrm{CO}$ content in the gas and presence of $\mathrm{CO}_{2}$ in the gas mix for sinter samples treated under simulated VP trial condition.

(2) Degradation takes place both at low temperature $\left(550\right.$ and $\left.650^{\circ} \mathrm{C}\right)$ and high temperature $\left(900\right.$ and $\left.1000^{\circ} \mathrm{C}\right)$ reduction for sinter samples tested under simulated SM test condition and VP trial condition.

(3) The major phases present in the untreated sinter sample are magnetite (45.3\%), SFCA (17.5\%), magnesioferrite $(9.5 \%)$, hematite $(9 \%)$, dicalcium ferrite [non-stoichiometric] $(7.5 \%)$ and wustite $(6.4 \%)$.

(4) The low SFCA content $(17.5 \%)$, more magnetite $(45.3 \%)$ and magnesiferrite phases $(9.5 \%)$ in the sinter results in poor reduction degree and formation of large holding zones in BF.

(5) Results validate the reasons for formation of large holding zone corresponding to low temperature degradation isotherms of $450-650^{\circ} \mathrm{C}$, larger thermal reserve zone (900$1000^{\circ} \mathrm{C}$ ) and a delayed formation of cohesive zone with narrow transition zone nearer to tuyere region of blast furnace as found by VP trials of BF No. 5, BSL. Therefore, low temperature holding zone has to be avoided and high temperature holding zone has to be minimized for avoiding sinter degradation. This can be achieved by increasing sinter reduction degree by adjusting sinter chemistry and burden distribution in blast furnace.

(6) Results of simulated VP trials of sinter clearly shows that BF simulation tests carried out for Softeningmelting properties of ferrous burden do not provide an indication of the state of the material at the initiation of direct reduction in actual blast furnace condition.

\section{REFERENCES}

1) C. E. Loo and N. J. Bristow: Ironmaking Steelmaking, 25 (1998), 222.

2) K.-H. Peters, E. Beppler and B. Gerstenberd: Ironmaking Conf. Proc., 49, ISS, Warrendale, PA, (1990), 277.

3) C. E. Loo and N. J. Bristow: Ironmaking Steelmaking, 25 (1998), 287.

4) K.-H. Peters, E. Beppler, B. Gerstenberg and U. Janhsen: Ironmaking Conf. Proc., 53, ISS, Warrendale, PA, (1994), 257.

5) P. R. Dawson: Ironmaking Steelmaking, 20 (1993), 137.

6) C. E. Loo and N. J. Bristow: Ironmaking Steelmaking, 25 (1998), 366.

7) T. Ya. Malysheva, Yu. S. Yusfin, M. F. Gibadulin, V. V. Korovushkin, N. R. Mansurova and V. A. Gostenin: Steel Transl., 36 (2006), 24.

8) M. Matsumura, M. Hoshi and T. Kawaguchi: ISIJ Int., 45 (2005), 594.

9) L. X. Yang and C. E. Loo: ISIJ Int., 37 (1997), 449. 